\title{
Depression, sexuality and fibromyalgia syndrome: clinical findings and correlation to hematological parameters
}

\author{
Depressão e sexualidade na síndrome fibromiálgica: achados clínicos e correlação com \\ parâmetros hematológicos \\ Bruna Alves 1,2, Telma M Zakka², Manoel J. Teixeira², Helena H. Kaziyama², Jose T. T. Siqueira3 , Silvia R. D. T. Siqueira1,2
}

\begin{abstract}
Fibromyalgia (FM) is characterized by chronic pain and comorbidities. Objective: To investigate sexuality and depression in women with FM compared with controls and to correlate the findings with hematological parameters. Methods: 33 women with FM and 19 healthy women were included and evaluated with the following instruments: Female Sexual Function Index, Beck Inventory, Visual Analogue Scale, medical history and laboratory exams. Results: The prevalence of sexual dysfunction $(P=0.007)$ and depression $(P<0.001)$ were higher in the study group than in the control group; they were positively correlated $(P=0.023)$. The study group showed lower serum concentrations of testosterone, free T4, antinuclear factor, and lower blood hemoglobin and hematocrit. Conclusions: FM was associated with high scores of sexual dysfunction and depression, and there were correlations with hematological parameters. We suggest the involvement of immuneinflammatory mediators and FM, which need further investigation to understand their role in FM syndrome and its comorbidities.
\end{abstract}

Keywords: fibromyalgia; depression; sexuality; hematologic tests

\section{RESUMO}

Fibromialgia (FS) é caracterizada por dor e comorbidades. Objetivo: investigar depressão e sexualidade em mulheres com FS comparadas a controles, e correlacionar os achados com parâmetros hematológicos. Métodos: 33 mulheres com FS e 19 controles saudáveis foram incluídas e avaliadas através dos seguintes instrumentos: Índice de Função Feminina Sexual, Inventário de Beck, escala visual analógica, história médica e exames laboratoriais. Resultados: A prevalência de disfunção sexual $(P=0,007)$ e depressão $(P<0,001)$ foram maiores no grupo de estudo do que nos controles; também houve correlação positiva ( $P=0,023)$. 0 grupo de estudo apresentou menor concentração sérica de testosterona, T4 livre, fator antinuclear e menos concentração de hemoglobina e hematócrito. Conclusões: A FS associou-se com altos índices de disfunção sexual e depressão, e houve correlação com os parâmetros hematológicos estudados. Sugere-se o envolvimento de mediadores imuno-inflamatórios na FS, que necessita de maior investigação para a compreensão dos mecanismos tanto na FS e quanto em suas comorbidades.

Palavras-chaves: fibromialgia; depressão; sexualidade; testes hematológicos.

Fibromyalgia (FM) is characterized by generalized pain, decreased pain thresholds, sleep disturbances, fatigue, edema, paresthesia and dysesthesia, morning stiffness with a short duration, psychological distress and chronic headache. It is often associated with articular and muscular pain, and inflammation ${ }^{1}$. There is a high prevalence of FM in adult women (4-7 times more common in women between 30 and 60 years old than in men or other ages) ${ }^{2}$.

The pathophysiology of FM is not yet clear ${ }^{2,3}$. It includes neurophysiological mechanisms such as altered concentrations of substance P, dynorphin and nerve growth factor in the cerebrospinal fluid, altered blood concentration of neuropeptide $\mathrm{Y}^{1}$, sensory abnormalities, altered NMDA receptors, deficit in the inhibitory pain system and other neurological disturbances ${ }^{2}$. Inflammatory observations show high serum concentrations of interleukin 10 (IL-10), IL-8 and tumoral necrosis factor ( $\mathrm{TNF} \alpha)$, correlated with clinical parameters ${ }^{3}$. Cytokines are associated with pain because of their role in central sensitization, which suggest their influence in FM and depression ${ }^{3}$.

\footnotetext{
'Universidade de São Paulo, Escola de Artes, Ciências e Humanidades, São Paulo SP, Brasil;

¿Universidade de São Paulo, Faculdade de Medicina, Centro Interdisciplinar de Dor, Departamento de Neurologia, São Paulo SP, Brasil;

${ }^{3}$ Universidade de São Paulo, Faculdade de Medicina, Hospital das Clínicas, Grupo de Dor Orofacial, São Paulo SP, Brasil.

Correspondence: Silvia R. D. T. de Siqueira; R Maria Candida, 135; 02071-010 São Paulo SP, Brasil; E-mail: silviadowgan@hotmail.com

Conflict of interest: There is no conflict of interest to declare.

Received 08 April 2016; Received in final form 13 June 2016; Accepted 12 July 2016
} 
Fibromyalgia patients have also sexual dysfunction $^{1,4,5,6}$ and reproduction problems ${ }^{5}$, as well as depression ${ }^{7}$. The mechanisms are unclear but seem to involve the hypothalamus-pituitary-adrenal axis, sexual hormones and cytokines $^{8}$. Depression affects the life of $83.3 \%$ patients with $\mathrm{FM}^{9}$ and, in Brazil, $67.2 \%$ of them have depression diagnosed as a comorbidity $^{10,11,12}$. Thus, the objectives of this study were to investigate the sexuality and depression in women with FM compared with controls, and to correlate the clinical findings to blood parameters.

\section{METHODS}

Thirty-three ( $\mathrm{n}=33$ ) women consecutively diagnosed as having FM in the period between November 2009 and September 2010 were included and evaluated in this study. They were compared to 19 healthy women (control group). The patients had been diagnosed at the Physical Medicine Division, Trauma and Orthopedic Institute, Hospital das Clínicas, Medical School, University of Sao Paulo, and had fulfilled the criteria of the American College of Rheumatology: chronic widespread pain (duration longer than six months), and at least 11 out of 18 possible tender points (widespread pain is defined as axial pain plus upper and lower segment plus left- and right-sided pain $)^{13}$.

The patients were instructed to keep taking their medication during the evaluation period, which they had been taking during the previous six months with no variation in doses. All women were informed about the purposes of this study and signed the informed consent. The project was previously approved by the local Ethics Committee.

Inclusion criteria of the study group: women with the diagnosis of FM according to the American College of Rheumatology criteria and more than six months of pain.

Inclusion criteria of the control group: healthy women with no complaint of pain during the last 12 months and no use of chronic medication.

Exclusion criteria of both groups: inflammatory or rheumatologic comorbidities (eg. rheumatoid arthritis, lupus erythematosus), diabetes mellitus, neurological diseases and hypothyroidism.

\section{Investigation of tender points}

The tender points exam was performed at the time of diagnosis on the day of the investigation, in all subjects by one observer (H.K.). A tender point was counted as "positive" if the pressure pain threshold was lower than $393 \mathrm{kPa}$ $\left(4 \mathrm{~kg} / \mathrm{cm}^{2}\right)^{13}$. An electronic pressure algometer (Somedic, Sweden) with a probe area of $1 \mathrm{~cm}^{2}$, which was pressed on the skin with a ramp rate of $50 \mathrm{kPa} / \mathrm{s}$, was used to determine the pressure pain threshold over the designated tender point areas. Tenderness at any point was considered if some involuntary verbal or facial expression of pain occurred or withdrawal was observed. All patients presented with at least 11 tender points, fulfilling the American College of Rheumatology criteria ${ }^{13}$.

The evaluation consisted of the following questionnaires, instruments of evaluation and examinations: (a) female sexual function index validated to the Portuguese language ${ }^{14}$; (b) beck inventory for the evaluation of depression, validated to the Portuguese language ${ }^{15}$; (c) visual analogue scale (only for the study group); (d) demographic data; (e) medical profile with data on the disease (pain characteristics, clinical exam, comorbidities); (f) laboratory exams: blood samples $(5 \mathrm{~mL})$ were collected for serum analysis of the concentration of the following substances: antinuclear factor, immunoglobulins (IgM, IgG, IgE), total proteins and fractions, rheumatoid factor, circulating immune complexes, complement factors $\mathrm{C} 3$ and $\mathrm{C} 4$, reactive $\mathrm{C}$ protein, complete hemogram with red and white series, platelets, albumin, globulin, thyroid-stimulating hormone (TSH), tetraiodothyronine (T4), free $\mathrm{T} 4$, triiodothyronine (T3), luteinizing hormone (LH), follicle-stimulating hormone, prolactin, estrogen, progesterone, testosterone, serum cortisol, and adrenocorticotrophic hormone (ACTH).

\section{Statistical analysis}

The sample size was calculated with a confidence interval of $95 \%$ comparing the prevalence of FM and correlated comorbidities at the pain clinic. All data were tabled and the frequencies and percentages, means, standard deviations and ranges were compared among the groups. After the initial descriptive evaluation, variables were tested around normal distribution with the Shapiro-Wilk test and Q-Q plots. For quantitative variables with normal distribution we used ANOVA 1 factor. Post hoc comparisons were calculated using the Tukey test. Non-parametric tests included Pearson's chisquare and Fisher's exact test. Correlations among the variables were tested with Pearson's. All statistical calculations were performed using SPSS 17.0 (SPSS Inc., Illinois,USA). The level of significance was $5 \%$.

\section{RESULTS}

The mean ages were 39.73 years (study group) and 30.79 years (control group). Statistical differences were found in ages, educational status and work activity (Table 1). The study group had higher serum concentrations of C4, T4, T3, rheumatoid factor and C-reactive protein (CRP) than the controls; the study group showed lower serum concentrations of testosterone, free T4, antinuclear factor, and lower blood hemoglobin and hematocrit than the control group (Table 2; Figures 1 and 2).

There were higher scores of sexual dysfunction (ANOVA, $\mathrm{p}<0.001$ ) and depression (ANOVA, $\mathrm{p}<0.001$ ) in the study group than the control group (Figures 3 and 4 ). The prevalence 
of sexual dysfunction (chi-square $\mathrm{p}=0.007$ ) and depression $(p<0.001)$ were higher in the study group than the control group as well. High sexual dysfunction was also correlated with depression $(p=0.023)$.

The following correlations were also observed in both groups: high depression with low concentration of antinuclear factor ( $p=0.048)$ and IgG ( $p=0.035)$; high sexual dysfunction with low concentrations of luteinizing hormone $(\mathrm{p}=0.031)$, follicular stimulant hormone $(\mathrm{p}=0.001)$ and platelets $(\mathrm{p}=0.002)$.

In the study group, high depression was correlated to high sexual dysfunction $(\mathrm{p}=0.003)$, high pain intensity on the Visual Analogue Scale $(p=0.005)$, high ACTH $(p=0.046)$ levels, high progesterone levels $(p=0.042)$, low C3 ( $\mathrm{p}=0.019)$ and low mean corpuscular volume in the blood count $(\mathrm{p}=0.034)$. Other correlations were: high pain intensity to high C3 and low IgM ( $p=0.019)$; high age to high estradiol $(\mathrm{p}=0.033)$ and cortisol $(\mathrm{p}=0.026)$. Menopause was associated with low concentration of rheumatoid factor $(p=0.008)$ and sexual dysfunction was associated with low levels of leucocytes $(p=0.029)$.
Table 1. Demographic and general comparison between the study group and the control group ( $n=52)$.

\begin{tabular}{|c|c|c|c|}
\hline Variable & $\frac{\text { Study Group }}{(n=33)}$ & $\begin{array}{c}\text { Control Group } \\
(n=19)\end{array}$ & $P *$ \\
\hline Ages (years) & $\begin{array}{c}39.73 \pm 6.31 \\
(29-49)\end{array}$ & $\begin{array}{c}30.79 \pm 8.43 \\
(21-48)\end{array}$ & 0.000 \\
\hline \multicolumn{4}{|l|}{ Educational status (\%) } \\
\hline Less than high school & 39.4 & 15.8 & \multirow{3}{*}{0.001} \\
\hline $\begin{array}{l}\text { Completed high } \\
\text { school }\end{array}$ & 57.6 & 47.4 & \\
\hline $\begin{array}{l}\text { Completed } \\
\text { undergraduation }\end{array}$ & 3.0: & 36.8 & \\
\hline \multicolumn{4}{|l|}{ Marital status (\%) } \\
\hline Single & 9.1 & 57.9 & \multirow{3}{*}{0.052} \\
\hline Married & 75.7 & 31.6 & \\
\hline Divorced & 15.2 & 10.5 & \\
\hline \multicolumn{4}{|l|}{ Work activity (\%) } \\
\hline Yes & 39.4 & 78.9 & 0.005 \\
\hline Menopause (\%) & 3.0 & 5.3 & 0.694 \\
\hline $\begin{array}{l}\text { Hormonal replacement } \\
(\%)\end{array}$ & 0.0 & 0.0 & - \\
\hline Contraceptive use (\%) & 21.2 & 10.5 & 0.314 \\
\hline
\end{tabular}

Table 2. Results of blood sample analysis: comparison between the study group and the control group ( $N=52)$.

\begin{tabular}{|c|c|c|c|}
\hline Variable & Study group $(n=33$ ) & Control group $(n=19)$ & $p^{* *}$ \\
\hline $\mathrm{ACTH}^{*}(\mathrm{pg} / \mathrm{ml})$ & $15.2 \pm 6.7(5.0-33.0)$ & $16.8 \pm 15.0(4.0-67.0)$ & 0.657 \\
\hline C3 (mg/dL) & $134.3 \pm 36.6(8.2-194.0)$ & $117.8 \pm 18.5(91.0-157.0)$ & 0.083 \\
\hline $\mathrm{C} 4$ (mg/dL) & $26.8 \pm 8.2(13-48)$ & $22.0 \pm 5.8(10.9-32.4)$ & 0.038 \\
\hline Estradiol (pg/mL) & $67.3 \pm 49.8(13.0-172.0)$ & $85.8 \pm 89.2(13.0-267.1)$ & 0.393 \\
\hline Progesterone (pg/mL) & $4.0 \pm 8.3(0.3-34.0)$ & $2.7 \pm 4.7(0.3-15.8)$ & 0.554 \\
\hline $\mathrm{LH}(\mathrm{pg} / \mathrm{mL})$ & $13,9 \pm 18.3(0.6-56.2)$ & $10.0 \pm 11.8(0.1-48.0)$ & 0.420 \\
\hline FHS (pg/mL) & $26.1 \pm 38.4(1.4-136.6)$ & $13.4 \pm 22.0(0.6-80.5)$ & 0.213 \\
\hline Prolactin $(\mathrm{pg} / \mathrm{mL})$ & $11.9 \pm 19.8(2.5-98.7)$ & $13.3 \pm 7.6(4.5-29.3)$ & 0.782 \\
\hline Testosterone (pg/mL) & $15.8 \pm 8.3(10.1-40.0)$ & $27.52 \pm 15.08(12-0-57.0)$ & 0.003 \\
\hline $\mathrm{TSH}(\mu \mathrm{U} / \mathrm{mL})$ & $2.9 \pm 2.2(0.5-8.1)$ & $1.8 \pm 0.9(0.9-4.4)$ & 0.072 \\
\hline T4 ( $\mu g / d L)$ & $9.1 \pm 1.5(6.5-12.7)$ & $8.0 \pm 1.8(5.6-14.0)$ & 0.040 \\
\hline Free T4 ( $\mu \mathrm{g} / \mathrm{dL})$ & $0.9 \pm 0.1(0.7-1.2)$ & $1.2 \pm 0.2(1.0-1.5)$ & 0.000 \\
\hline T3 (pg/dL) & $145.3 \pm 24.7(98.0-197.0)$ & $119.2 \pm 28.5(76.0-194.0)$ & 0.003 \\
\hline Cortisol ( $\mu \mathrm{g} / \mathrm{dL})$ & $8.9 \pm 3.8(1.6-17.2)$ & $10.0 \pm 5.5(3.3-21.4)$ & 0.419 \\
\hline Hemoglobin (g/dL) & $12.9 \pm 1.2(9.5-15.4)$ & $13.7 \pm 1.2(10.4-15.4)$ & 0.059 \\
\hline Hematocrit (\%) & $38.7 \pm 3.2(31.5-44.6)$ & $41.0 \pm 3.3(31.5-45.2)$ & 0.034 \\
\hline Mean corpuscular volume (\%) & $81.8 \pm 23.7(8.1-96.8)$ & $89.6 \pm 3.7(79.3-96.7)$ & 0.167 \\
\hline Mean corpuscular hemoglobin (\%) & $29.6 \pm 2.4(23.6-32.5)$ & $29.8 \pm 1.5(26.2-31.9)$ & 0.747 \\
\hline Mean corpuscular hemoglobin concentration (\%) & $33.3 \pm 1.4(30.2-35.7)$ & $33.3 \pm 1.1(31.1-35.8)$ & 0.965 \\
\hline Red cell distribution width (uug) & $13.6 \pm 1.1(11.8-16.0)$ & $13.3 \pm 0.6(12.3-14.9)$ & 0.200 \\
\hline Platelets $\left(\mathrm{ml} / \mathrm{mm}^{3}\right)$ & $268.1 \pm 58.7(170.0-343.0)$ & $269.6 \pm 45.0(187.0-352.0)$ & 0.936 \\
\hline $\mathrm{CRP}(\mathrm{mg} / \mathrm{L})$ & $7.0 \pm 7.5(0.3-32.6)$ & $1.7 \pm 1.6(0.2-5.3)$ & 0.005 \\
\hline $\lg E(U \mid / m L)$ & $88.1 \pm 110.9(6.0-472.0)$ & $104.3 \pm 117.8(5.0-413.0)$ & 0.681 \\
\hline $\operatorname{lgG}(\mathrm{UI} / \mathrm{mL})$ & $1183.6 \pm 221.1(801.0-1545.0)$ & $1168.9 \pm 124.6(981.0-1459.0)$ & 0.808 \\
\hline $\operatorname{lgM}(U \mathrm{U} / \mathrm{mL})$ & $111.1 \pm 71.5(48.5-358.1)$ & $130.5 \pm 38.7(60.2-199.4)$ & 0.324 \\
\hline Total protein $(\mathrm{g} / \mathrm{dL})$ & $7.3 \pm 0.4(6.5-8.1)$ & $7.2 \pm 0.3(6.8-7.9)$ & 0.583 \\
\hline Leucocytes (mil mm³) & $7.285 .9 \pm 1.939 .1(2.9-12.3)$ & $7.847 .4 \pm 2.417 .9(4.7-14.2)$ & 0.414 \\
\hline
\end{tabular}

${ }^{*} \mathrm{ACTH}$ :adrenocorticotrophic hormone;C3:complement factor 3;C4:complement factor 4; LH:luteinizing hormone; IgE:immunoglobulin E; IgG:immunoglobulin G; IgM: immunoglobulin M; FSH: follicle-stimulating hormone;CRP: C-reactive protein; TSH:thyroid stimulant hormone; T3: triiodothyronine; T4: tetraiodothyronine. **oneway ANOVA; Bold means significant; Results are presented in Mean \pm Standard Deviation (Minimum-Maximum). 


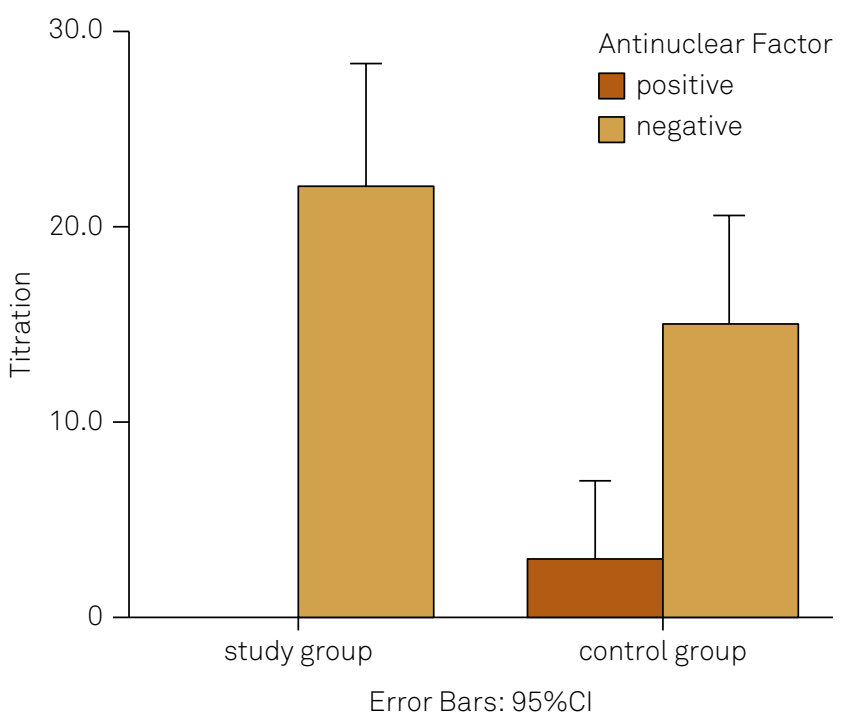

Figure 1. Antinuclear factor: comparison between the study and control groups $(p=0.048)$.

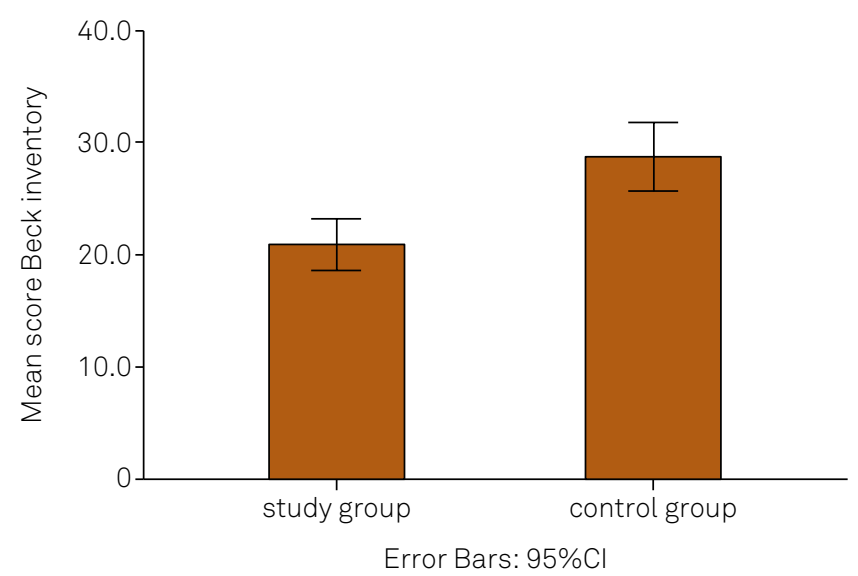

Figure 3. Mean sexual dysfunction scores: comparison between the study and control groups ( $p=0.000)$.

\section{DISCUSSION}

This study showed a significant association between sexual dysfunction and depression in FM patients. Sexual dysfunction can interfere in the quality of life and aggravate FM symptoms and depression, a frequent comorbidity of FM. The pathophysiological mechanisms seem to involve the peripheral and central nervous systems, hormones and/or immune-inflammatory mediators ${ }^{4,8,9}$, and hormonal variation associated with stress and the climacteric syndrome ${ }^{16,17}$. The search for clinical evidence is necessary to understand the role of comorbidities in FM and new possible approaches to assess these patients.

Sexual dysfunction and depression are important comorbidities that aggravate the clinical picture and reduce the quality of life of patients with FM. The treatment of chronic pain is complex and interdisciplinary, and the assessment of associated conditions is crucial to improve pain alleviation

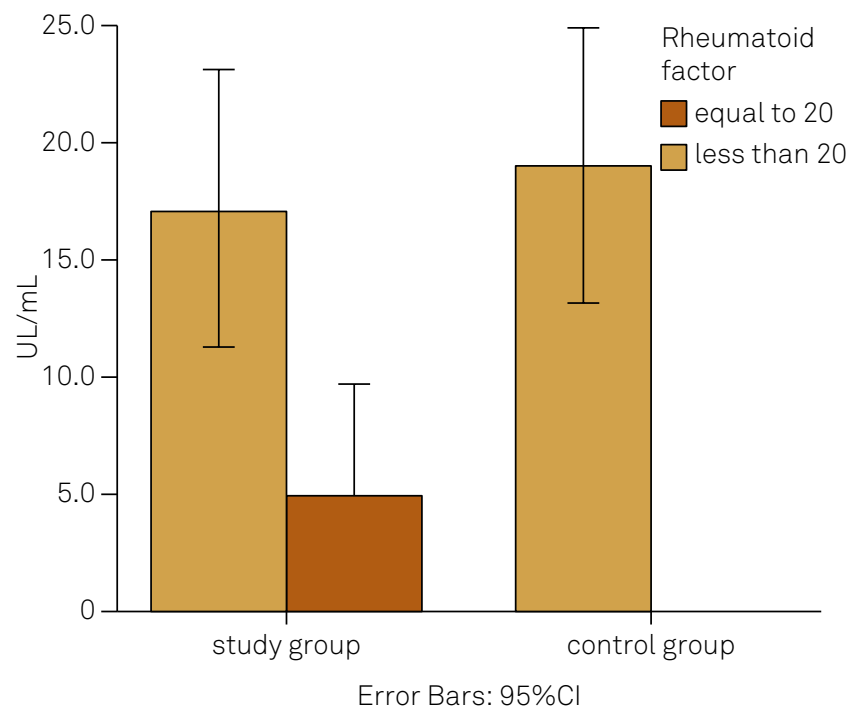

Figure 2. Rheumatoid factor: comparison between the study and control groups $(p=0.027)$.

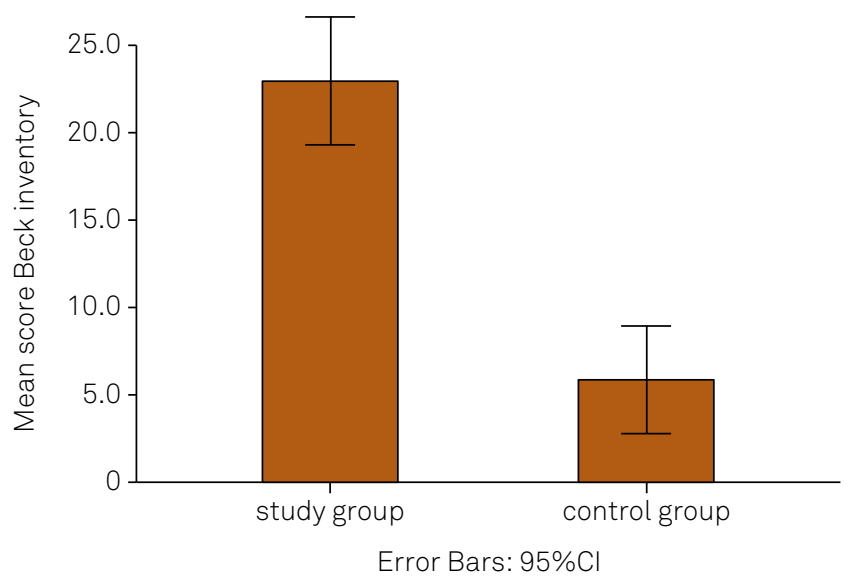

Figure 4. Mean depression scores: comparison between the study and control groups ( $p=0.000)$.

and to rehabilitate the patient, thus avoiding a new pain crisis $^{11,12,18}$. Symptomatic treatment needs to be followed by other non-pharmacological strategies, such as physiotherapy, psychotherapy, and the adaptation of the patient to general daily activities, leisure and work ${ }^{5}$. Previous studies support our findings, but the mechanisms that are underlying these associations are lacking ${ }^{6,7}$. Studies with longitudinal designs would also contribute to the understanding of caseeffect factors. The current knowledge of the biological background will be discussed.

Fibromyalgia is associated with an increase in inflammatory activity ${ }^{18,19}$, which is supported by the higher concentration of CRP, rheumatoid factor and complement in patients than in controls. It is known that cytokines such as IL- $1 \beta$, TNF- $\alpha$ and IL- 6 can trigger the inflammatory activity of $\mathrm{FM}^{3,19}$, and hormonal/neuronal mechanisms are probably behind this. Inflammatory mediators and cytokines can act in bone marrow and increase the production of blood 
cells, resulting in high hematocrit and blood hemoglobin, as observed in this study ${ }^{20,21}$. As well, they act in hepatocytes, altering CRP, rheumatoid factor, and complement concentrations ${ }^{21,22,23}$. The pain intensity was high in patients who had a high concentration of ACTH and $\mathrm{C} 3$ and low concentration of immunoglobulins, which suggests a cellular immune process mediated by $\mathrm{T}$ cells. These are cytokine releasers that are found to be activated in $\mathrm{FM}^{3,19,20,21,22,23}$.

The role of hormones in FM has been investigated, and the decline of sexual hormones in the climacteric syndrome could even be a potential etiology for $\mathrm{FM}^{17}$. Hormones are found to be altered in FM patients and they have direct influence in neurological and immunological functioning. ACTH and cortisol levels are linked to stress, pain and depres$\operatorname{sion}^{20}$, and were altered in this sample. This could indicate an imbalance of feedback mechanisms of stress and inflammation $^{16,19,20,21,22}$, although the activation or suppression of the hypothalamus-pituitary-adrenal axis in FM remains controversial $^{23,24}$. Besides the activation of the hypothalamus-pituitary-adrenal axis, there are low concentrations of dehydroepiandrosterone in FM patients ${ }^{25}$.

Testosterone was another hormone that we found in lower concentration in the study group than the control group, and it is known that low levels of testosterone may play a role in sexual dysfunction and depression in $\mathrm{FM}^{26,27}$.
Although the subjects included in this sample did not have thyroid diseases, there was a statistical difference in the concentration of thyroid hormones between the groups and this may play a role in pain and emotional comorbidities ${ }^{28}$. Besides the neurological and inflammatory mechanisms involved in FM, hormonal abnormalities should be considered in the pathophysiological process, or even as an etiology for FM. They could be targets to improve pain and its comorbidities in this complex syndrome, although a study with dehydroepiandrosterone for FM showed negative results ${ }^{29}$.

A limitation of this study was the age differences between the groups, which could influence the results. It is known that there is a decline in sexual hormones with aging, especially after menopause, and other findings from laboratory tests may be altered by this age.

In conclusion, the study group had higher scores of sexual dysfunction and depression $(\mathrm{p}<0.001)$ than the controls, and their prevalence was also higher $(p=0.007$ and $p=0.001$ respectively). Fibromyalgia was associated with high serum concentrations of C4, T4, T3, rheumatoid factor and CRP, high blood hemoglobin and hematocrit, and low testosterone, free T4, and antinuclear factor. This study shows evidence of inflammatory activity in FM patients, which needs further investigation to understand the role of these findings in the pathophysiological mechanisms of this disease and in its comorbidities.

\section{References}

1. Kalichman L. Association between fibromyalgia and sexual dysfunction in women. Clin Rheumatol. 2009;28(4):365-9. doi:10.1007/s10067-009-1093-3

2. Weidebach WFS. [Fibromyalgia: evidende of a neurophysiological evidence]. Rev Assoc Med Bras. 2002;48(4):291. Portuguese. doi:10.1590/S0104-42302002000400028

3. Gur A, Karakoc M, Erdogan S, Nas K, Cevik R, Sarac AJ. Regional cerebral blood flow and cytokines in young females with fibromyalgia. Clin Exp Rheumatol. 2000;20:753-60.

4. Ryan S, Hill J, Thwaites C, Dawes P. Assessing the effect of fibromyalgia on patients sexual activity. Nurs Stand. 2008;23(2):3541. doi:10.7748/ns2008.09.23.2.35.c6669

5. Shaver JL, Wilbur J, Robinson FP, Wang E, Buntin MS. Women's health issues with fibromyalgia syndrome.J Womens Health. 2006;15(9):1035-45. doi:10.1089/jwh.2006.15.1035

6. Kingsberg SA, Woodard T. Female sexual dysfunction: focus on low desire. Obstet Gynecol. 2015;125(2):477-86. doi:10.1097/AOG.0000000000000620

7. Kayhan F, Küçük A, Satan Y, Illgün E, Arslan Ș, lilik F. Sexual dysfunction, mood, anxiety, and personality disorders in female patients with fibromyalgia. Neuropsychiatr Dis Treat. 2016;12:34955. doi:10.2147/NDT.S99160

8. Avitsur R, Yirmiya R. The immunobiology of sexual behavior: gender differences in the suppression of sexual activity during illness. Pharmacol Biochem Behav. 1999;64(4):787-96. doi:10.1016/S0091-3057(99)00165-3

9. Aguglia A, Salvi V, Maina G, Rossetto I, Aguglia E. Fibromyalgia syndrome and depressive symptoms: comorbidity and clinical correlates.J Affect Disord. 2011;128(3):262-6. doi:10.1016/j.jad.2010.07.004
10. Lange M, Petermann F. [Influence of depression on fibromyalgia: a systematic review]. Schmerz. 2010;24(4):326-33. German. doi:10.1007/s00482-010-0937-8

11. Berber JSS, Kupek E, Berber SC. [Prevalence of depression and its correlation with quality of life in patients with fibromyalgia syndrome]. Rev Bras Reumatol. 2005;45:47-54. Portuguese. doi:10.1590/S0482-50042005000200002

12. Santos AMB, Assumpção A, Matsutani LA, Pereira CAB, Lage LV, Marques AP. [Depression and quality of life in patients with fibromyalgia]. Rev Bras Fisioterapia. 2006;10:317-24. doi:10.1590/S1413-35552006000300011

13. Wolfe F, Smythe HA, Yunus MB, Bennett RM, Bombardier C, Goldenberg G et al. The American College of Rheumatology 1990 criteria for the classification of fibromyalgia... Arthritis Rheum. 1990;33(2):160-72. doi:10.1002/art.1780330203

14. Thiel RRC, Dambros M, Palma PCR, Thiel M, Riccetto CLZ, Ramos MF. [Translation into Portuguese, cultural adaptation and validation of Female Sexual Function Index]. Rev Bras Ginecol Obstetr. 2008;30(10):504-10. Portuguese. doi:10.1590/S0100-72032008001000005

15. Gorestein C, Andrade L. Inventory of depression of Beck: psychometric properties of the Portuguese version. Rev Psiquiatr Clin (Santiago). 1998;25:245-50.

16. Geenen R, Jacobs JW, Bijlsma JW. Evaluation and management of endocrine dysfunction in fibromyalgia. Rheum Dis Clin North Am. 2002;28(2):389-404. doi:10.1016/S0889-857X(01)00009-6

17. Blümel JE, Palacios S, Legorreta D, Vallejo MS, Sarra S. Is fibromyalgia part of the climacteric syndrome? Maturitas. 2012;73(2):87-93. doi:10.1016/j.maturitas.2012.06.001 
18. Tikiz C, Muezzinoglu T, Pirildar T, Taskn EO, Frat A, Tuzun C. Sexual dysfunction in female subjects with fibromyalgia.J Urol. 2005;174(2):620-3. doi:10.1097/01.ju.0000165155.33511.eb

19. Bote ME, Garcia JJ, Hinchado MD, Ortega E. Fibromyalgia: anti-inflammatory and stress responses after acute moderate exercise. PLoS One. 2013;8(9):e74524. doi:10.1371/journal.pone.0074524

20. Juruena MF, Cleare AJ, Pariante CM. The hypothalamic pituitary adrenal axis, glucocorticoid receptor function and relevance to depression. Rev Bras Psiquiatr. 2004;26(3):189-201. doi:10.1590/S1516-44462004000300009

21. Bote ME, García JJ, Hinchado MD, Ortega E. Inflammatory/ stress feedback dysregulation in women with fibromyalgia. Neuroimmunomodulation. 2012;19(6):343-51. doi:10.1159/000341664

22. Parker AJ, Wessely S, Cleare AJ. The neuroendocrinology of chronic fatigue syndrome and fibromyalgia. Psychol Med. 2001;31(8):1331-45. doi:10.1017/S0033291701004664

23. Calis M, Gökçe C, Ates F, Ulker S, Izgi HB, Demir H, et al. Investigation of the hypothalamo-pituitary-adrenal axis (HPA) by 1 microg ACTH test and metyrapone test in patients with primary fibromyalgia syndrome. J Endocrinol Invest. 2004;27(1):42-6. doi:10.1007/BF03350909
24. Neeck G. Neuroendocrine and hormonal perturbations and relations to the serotonergic system in fibromyalgia patients. Scand J Rheumatol. 2000;113(113):8-12. doi:10.1080/030097400750001743-1

25. Finckh A, Berner IC, Aubry-Rozier B, So AK. A randomized controlled trial of dehydroepiandrosterone in postmenopausal women with fibromyalgia. J Rheumatol. 2005;32(7):1336-40.

26. Kumsar Ș, Kumsar NA, Sağlam HS, Köse O, Budak S, Adsan Ö. Testosterone levels and sexual function disorders in depressive female patients: effects of antidepressant treatment. J Sex Med. 2014;11(2):529-35. doi:10.1111/jsm.12394

27. Reis SL, Abdo CH. Benefits and risks of testosterone treatment for hypoactive sexual desire disorder in women: a critical review of studies published in the decades preceding and succeeding the advent of phosphodiesterase type 5 inhibitors. Clinics (São Paulo). 2014;69(4):294-303. doi:10.6061/clinics/2014(04)11

28. Ribeiro LS, Proietti FA. Interrelations between fibromyalgia, thyroid, autoantibodies, and depression. J Rheumatol. 2004;31(10):2036-40.

29. Peixoto C, Devicari Cheda JN, Nardi AE, Veras AB, Cardoso A1. The effects of dehydroepiandrosterone (DHEA) in the treatment of depression and depressive symptoms in other psychiatric and medical illnesses: a systematic review. Curr Drug Targets. 2014;15(9):901-14. doi:10.2174/1389450115666140717111116 